\title{
Efficiency of Fetuin-A and Procalcitonin in the Diagnosis of Infection in Patients with Febrile Seizure
}

\author{
Hussein Kadhem Al-Hakeim¹, Azhar Mohammed Al-Ankoshy², Mohammed-R.Alsharifi² \\ ${ }^{1}$ Department of Chemistry, Faculty of Science, Kufa University, Iraq \\ ${ }^{2}$ The Humanities and Science University, Department of Pathological Analysis Techniques, Najaf City, Iraq

\section{SUMMARY}

Fetuin-A is a negative acute phase reactant, while procalcitonin is an indicator of severe bacterial infection. Diagnosis of bacterial infection in febrile seizure (FS) is important for choosing the most suitable treatment. In this study, serum fetuin-A was estimated, for the first time, in the inpatients with FS and compared with procalcitonin and blood culture tests.

A total of 60 children ( 28 male and 32 female) with FS in addition to 30 sex- and age-matched children participated in the study. Patients were classified according to sex, age, PCT level (high PCT $>0.5 \mathrm{ng} / \mathrm{mL}$ ), C-reactive protein (CRP, positive $>6 \mathrm{mg} / \mathrm{L}$ ), and according to the results of the blood culture.

Fetuin-A level decreased and PCT level increased in FS patients in comparison to those in the control group. These changes are significantly increased $(p<0.05)$ in the positive CRP group compared with that of the negative CRP group. Kernel density estimation showed that procalcitonin is a better indicator of the infection in FS children than fetuin-A. Procalcitonin is more sensitive and specific than fetuin-A and when used together they produce $100 \%$ sensitivity and specificity for the diagnosis of bacterial infection in FS patients.

Fetuin-A is low in FS patients and can be used with procalcitonin in the diagnosis of bacterial infection in FS.

Key words: fetuin-A, procalcitonin, infection, febrile seizure

Corresponding author:

Hussein Kadhem Al-Hakeim

e-mail: headm2010@yahoo.com 


\section{INTRODUCTION}

Febrile seizure (FS) is defined according to the American Academy of Pediatrics guideline as a seizure accompanied by fever (temperature $\geq 38^{\circ} \mathrm{C}$ ) (1). It is the most common cause of seizures in children with unknown etiology (2) that affects $2 \%$ to $5 \%$ of children between 3 months and 5 years of age (1).One of the possible causes of FS is sepsis. Therefore, it is important to detect and distinguish it from other causes in order to choose the most suitable treatment of FS. Sepsis is an inflammatory response by macrophages to the bacterial infection, and losing the control of on the systemic inflammation may harmfully contribute to the development of sepsis (3).

Many biomarkers were tested for the diagnosis of FS including CD4+/CD8+ ratio (4), cell free plasma DNA (5), S100B protein (6), metalloproteinases and proinflammatory cytokines (7), Srp9 gene (8) copeptin (9), and procalcitonin (10). However, none of these biomarkers has sufficient and acceptable specificity and sensitivity. In the present study, the role of fetuin-A in the diagnosis of bacterial febrile seizure was estimated for the first time and compared with the procalcitonin that extensively studied marker for sepsis in FS.

Procalcitonin (PCT) has been proposed as a marker of septicemia in FS with highly acceptable diagnostic efficiency in patients with sepsis and bacterial infection (11), because of its diagnostic accuracy and good correlation with the etiology and severity of infection (7). Presently, some physician use PCT to differentiate FS patients with bacterial and nonbacterial infectious causes (12).

Fetuin-A, a negative acute phase protein reactant (13), acts as a carrier protein of the insoluble calcium phosphate (14). Serum total fetuin-A concentrations are reduced in patients with chronic inflammatory disease (15) and children with infection (16).

Fetuin-A can bind to some types of bacteria (17) and prevent necrosis and leakage of injurious molecules (e.g., proteases, reactive oxygen species, and High-mobility group protein B1) (18). In the present research, serum PCT and fetuin-A would be measured in children with FS to estimate the most sensitive and specific factor related to the bacterial infection in FS children.

\section{SUBJECTS AND METHODS}

\section{Subjects}

Sixty children (28 male and 32 female) with FS participated in the study. The included patient's age range was between 8-37 months. The patients were recruited from the Al-Husseini Hospital in Karbala Governorate and some health centers in Najaf CityIraq, from September 2014 to January 2015. Blood sampling was performed within few hours from the attack. A complete clinical investigation was performed by a specialized pediatrician. The consents were obtained, for patients and healthy groups, from their first degree relatives (mother or father) who were informed that the results of the study will be given to them as a free useful laboratory tests. The conditions of the Ethics Committee of the Iraqi Ministry of Health were followed in the study. The patients were treated with antibiotics, and some patients with positive blood culture (8 out of 60) responded to the treatment, indicating bacterial infection or septicemia.

Exclusion Criteria: This study excluded any child who did not respond to antibiotic treatment and suspected to have epilepsy, viral, and fungal infections. Moreover, patients with any evident major systemic diseases, including diabetes mellitus, cardiac problems, or other endocrine disorders were excluded as well.

Thirty healthy children were selected as the control group. Their age range was comparable with that of the patients. None of these control subjects had any systemic or endocrine disorder. All the control subjects had negative CRP, i.e. had no infection or inflammation.

\section{Methods}

Serum PCT was measured using ready-to-use ELISA kits supplied by DRG ${ }^{\circledR}$ InternationalInc., USA. The human PCT ELISA is a sandwich-enzyme immunoassay for measuring human PCT.

Serum fetuin-A and estradiol (E2) were measured using ELISA kits supplied by Monobind ${ }^{\circledR}$ (USA). 


\section{Statistical analysis}

For the normally distributed variables, examined using the Kolmogorov-Smirnov test, the results were expressed as the mean \pm standard deviation. Pooled t-test was used to compare means between the patient and control groups and among subdivided groups in the measured parameters. Pearson's correlation coefficients ( $r$ ) were used to estimate the correlation between parameters.

For nonparametric variables that were not normally distributed, the results were expressed as medians, in addition to the mean \pm standard deviation. Mann-Whitney $U$ test was used to compare the medians between the groups and among subdivided groups in the measured parameters. The correlation between nonparametric variables was estimated using Spearman's correlation coefficients (Q, rho).

The difference between groups was considered statistically significant when $p<0.05$. All statistical analyses were performed using SPSS Statistics version 21 (2013, IBM, USA). Kernel density estimation and other figures were constructed using EXCEL
(Microsoft Office 2010) supplied with add-in for the Kernel density estimation.

\section{RESULTS}

\section{Comparison between FS patients and control groups}

Table 1 shows that there is a highly significant reduction in the concentration of fetuin- $A(p=0.008)$ and a highly significant elevation in serum procalcitonin $(p<0.0001)$ in the patients with FS in comparison with the healthy control.

Serum fetuin-A and procalcitonin are ageindependent and were not significantly different between male and female patients with FS.

\section{Kernel density distributions}

Kernel density estimation of the distribution of individual fetuin-A and procalcitonin level in the patients and control groups are presented in Figure 1 and 2, respectively.

Table 1: Serum fetuin-A and procalcitonin in the patients with FS and healthy control group

\begin{tabular}{lccc}
\hline \hline Parameter & Patient Mean (Range) & Control Mean (Range) & p-value \\
Fetuin- $\mathrm{A}(\mu \mathrm{g} / \mathrm{ml})$ & $374.4(28.8-1268.1)$ & $652.3(216.2-1410.3)$ & 0.008 \\
Procalcitonin $(\mathrm{ng} / \mathrm{ml})$ & $11.5(1.1-41.23)$ & $0.7(0.2-1.6)$ & $<0.0001$ \\
\hline \hline
\end{tabular}

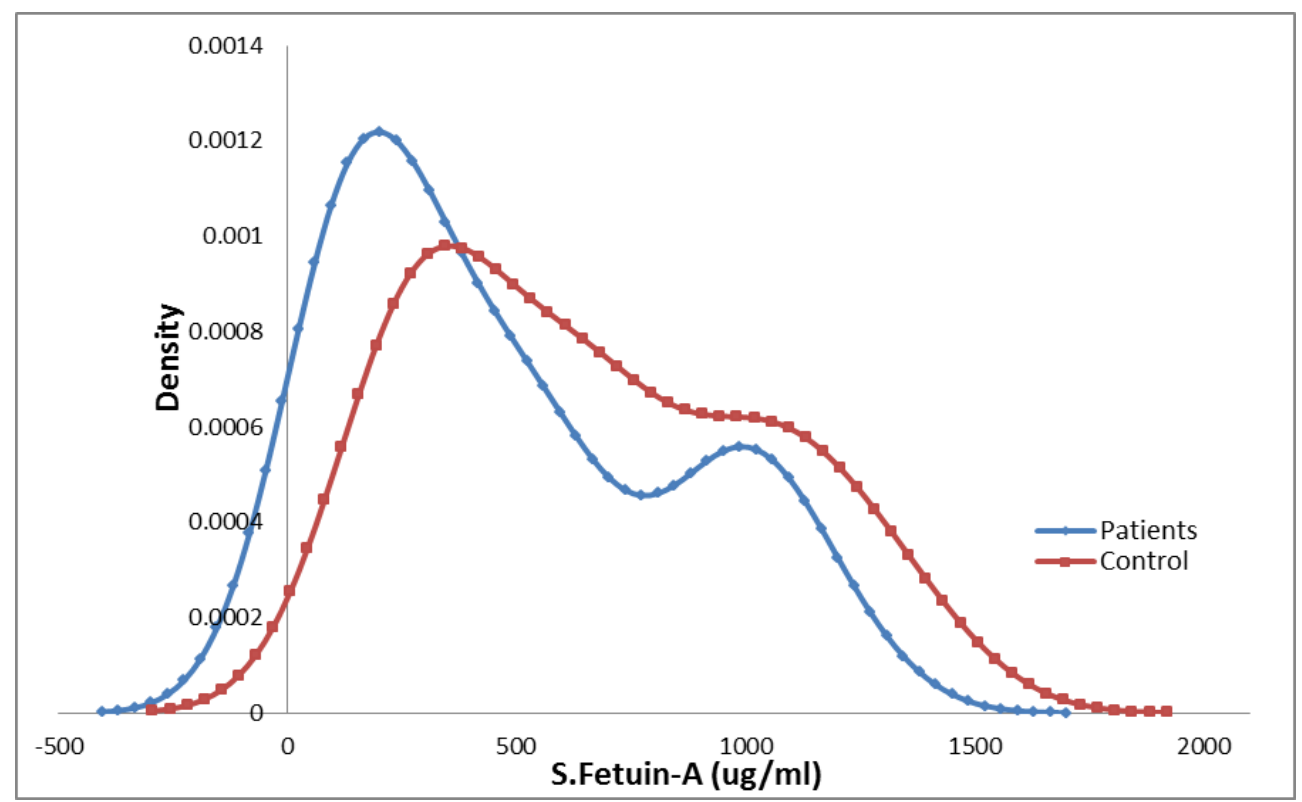

Figure 1: Kernel density Estimation of the distribution of individual fetuin-A level in the patients and control groups with bandwidth of 144.31 


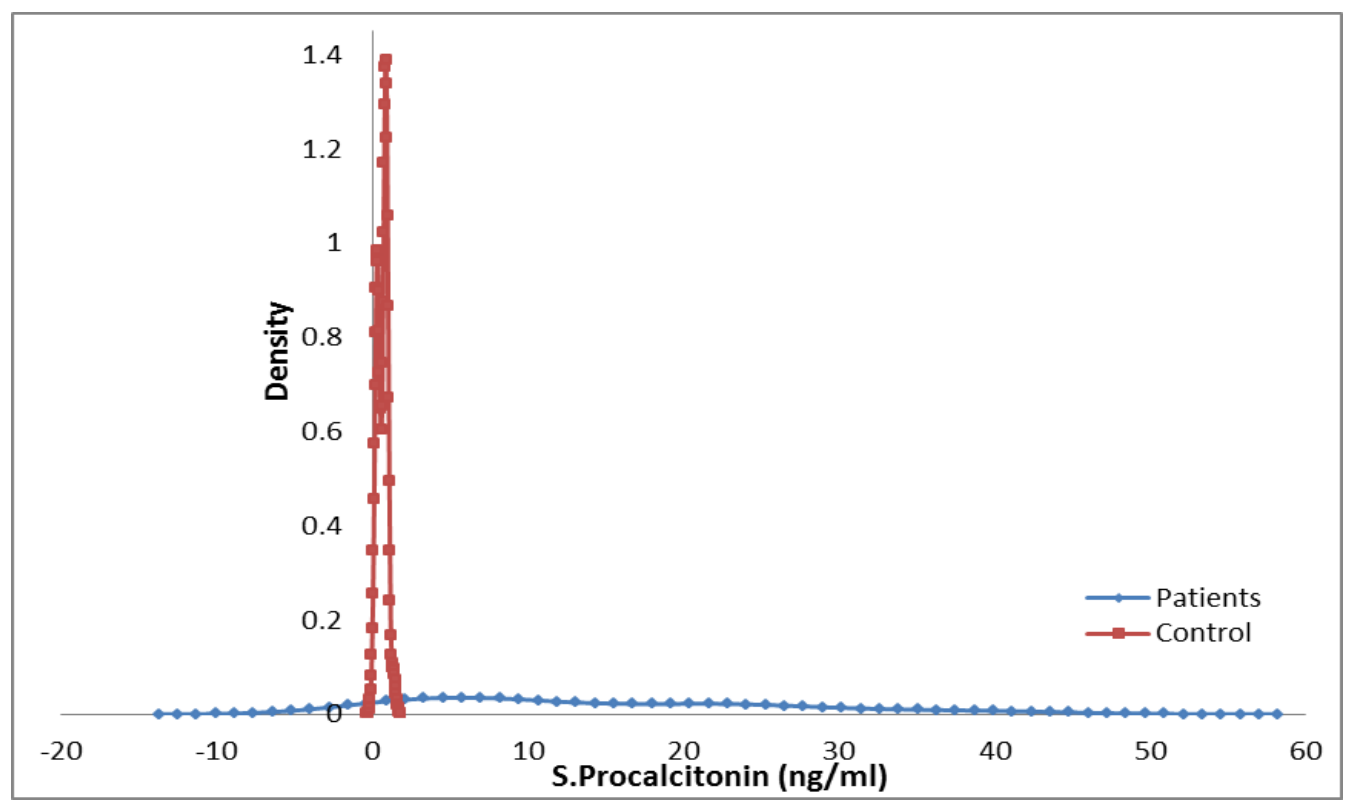

Figure 2: Kernel density estimation of the distribution of individual PCT level in the patients and control groups with bandwidth of 0.14 .

The results indicated that the distribution of the fetuin-A values of patient and control groups are close to each other, while there is a wide difference between the procalcitonin level in the patient group in comparison with the control group. Control group showed a narrow difference between the results, while the results of FS patients are distributed on a wide range of values. From these results, procalcitonin measurement is a better conclusive measurement in comparison with fetuin-A values.

\section{Comparison between positive and negative CRP patient groups}

Eleven patients out of 60 had positive CRP $(\mathrm{CRP}>6 \mathrm{mg} / \mathrm{l})$. Table 2 shows the medians of fetuin-A and procalcitonin in FS patients with positive CRP and negative $C R P(C R P<6 \mathrm{mg} / \mathrm{l})$. There is a significant increase $(p<0.001)$ in the procalcitonin level and significant decrease $(p<0.001)$ in the fetuin-A level in patients with positive CRP in comparison with the patients with negative CRP.

\section{Comparison between FS patients with positive and negative blood culture}

Eight out of 60 patients (13.3\%) had positive blood culture. The comparison between the patients with negative and positive blood culture results showed that there are significant differences $(p<0.05)$ between positive and negative blood culture groups in the level of PCT $(18.38 \mathrm{ng} / \mathrm{ml}$ vs. $0.77 \mathrm{ng} / \mathrm{ml})$ and fetuin-A $(64.13 \mu \mathrm{g} / \mathrm{ml} v s .706 .26 \mu \mathrm{g} / \mathrm{ml})$, respectively. The sensitivity and specificity are $100 \%$ for the following criteria of septicemia (CRP $>6 \mathrm{mg} / \mathrm{l}$, procalcitonin $>0.5 \mathrm{ng} / \mathrm{ml}$, fetuin- $\mathrm{A}<600 \mu \mathrm{g} / \mathrm{ml}$ ) i.e., we can substitute the culture by these tests for the diagnosis of septicemia.

Table 2: Serum fetuin-A and procalcitonin in patients with FS and healthy control

\begin{tabular}{lccc}
\hline \hline Parameter & +Ve CRP Mean (Range) & -Ve CRPMean (Range) & p-value \\
Fetuin-A $(\mu \mathrm{g} / \mathrm{ml})$ & $88.4(28.8-268.1)$ & $506.6(118.7-1268.0)$ & $<0.001$ \\
Procalcitonin $(\mathrm{ng} / \mathrm{ml})$ & $21.0(2.8-44.1)$ & $7.9(0.2-37.2)$ & $<0.001$ \\
\hline \hline
\end{tabular}




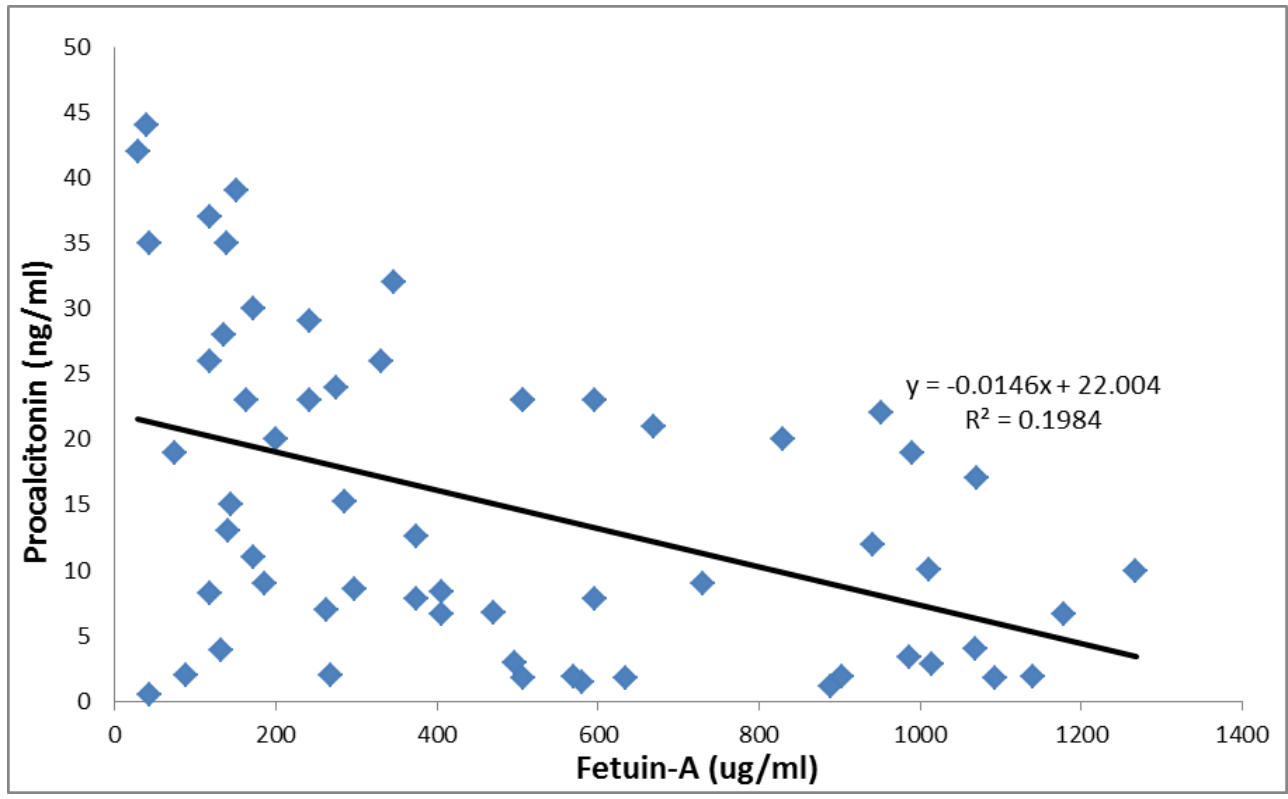

Figure 3: Correlation between fetuin-A and procalcitonin in the patient group

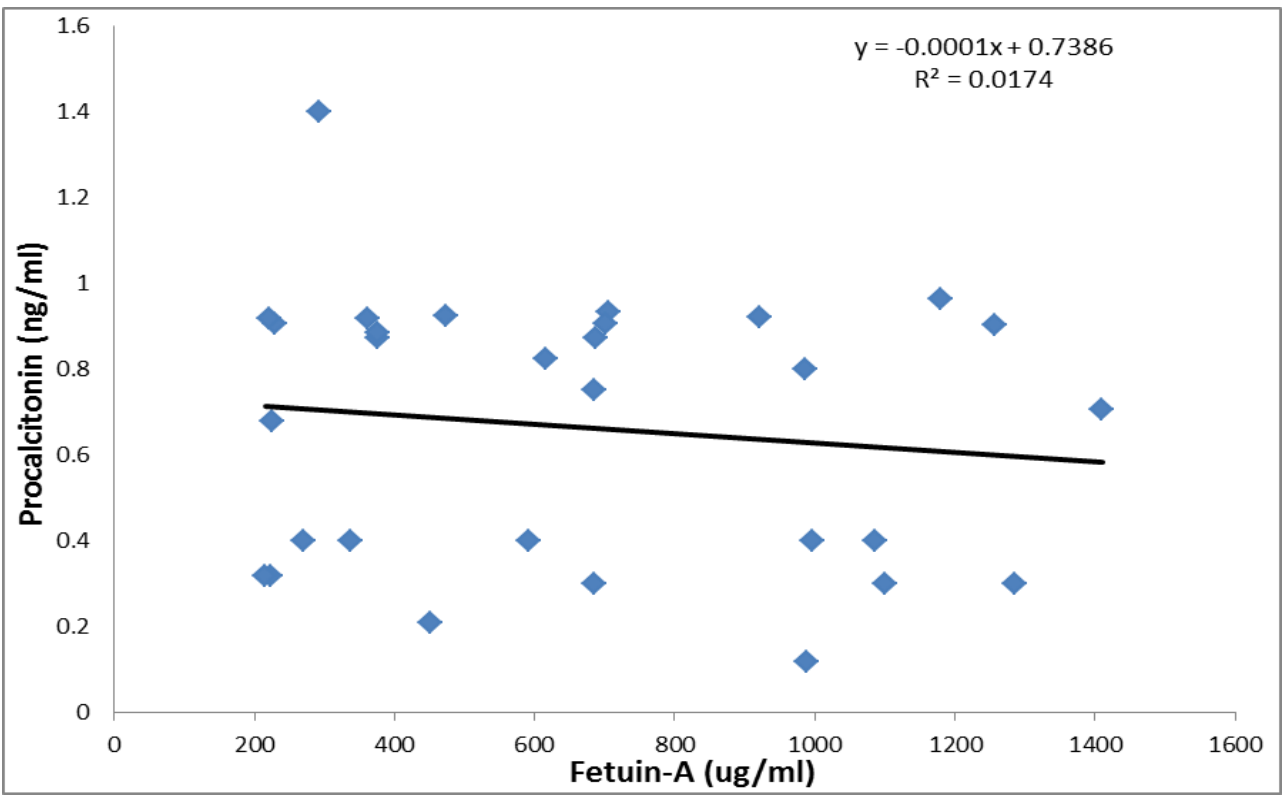

Figure 4: Correlation between fetuin-A and procalcitonin in the control group

\section{Correlation between fetuin-A and procalcitonin}

The study of the relationship between the levels of fetuin-A and procalcitonin in patient and control groups are presented in Figure 3 and 4 . The results showed a highly significant negative correlation between these parameters in the patient group $\left(\mathrm{R}^{2}=0.1984, \mathrm{Q}=-0.436, \mathrm{p}<0.001\right)$ and a lack of correlation in the control group $\left(\mathrm{R}^{2}=0.0174, \mathrm{Q}=-0.076, \mathrm{p}=0.689\right)$.
Sensitivity, specificity and accuracy

Calculation of the sensitivity, specificity, accuracy and negative and positive predictive values of FS patient and control groups are presented in Table 3. The cut-off value for PCT was taken at PCT $>0.5 \mathrm{ng} / \mathrm{ml}$ at which 46 out of 60 patients in addition to 12 out of 30 control group had higher than the cut-off value. For fetuin-A, three different cut-off values were taken. The sensitivity and accuracy increased and specificity decreased as the cut-off 
Table 3. Predictive values of fetuin-A and procalcitonin in FS patients and control groups

\begin{tabular}{lcccc}
\hline \hline & PCT $>\mathbf{0 . 5 n g} / \mathbf{m l}$ & $\begin{array}{c}\text { Fetuin-A } \\
<\mathbf{4 0 0} \boldsymbol{\mu g} / \mathbf{m l}\end{array}$ & $\begin{array}{c}\text { Fetuin-A } \\
\mathbf{5 0 0} \boldsymbol{\mu g} / \mathbf{m l}\end{array}$ & $\begin{array}{c}\text { Fetuin-A } \\
<\mathbf{6 0 0} \boldsymbol{\mu g} / \mathbf{m l}\end{array}$ \\
Sensitivity & 76.7 & 53.3 & 58.3 & 70.0 \\
Specificity & 60.0 & 63.3 & 56.7 & 56.7 \\
PPV & 79.3 & 74.4 & 72.9 & 76.4 \\
NPV & 56.3 & 40.4 & 40.5 & 48.6 \\
Accuracy & 71.1 & 56.7 & 57.8 & 65.6 \\
\hline \hline
\end{tabular}

value increased from $<400 \mu \mathrm{g} / \mathrm{ml}$ to $<600 \mu \mathrm{g} / \mathrm{ml}$. The number of subjects who had serum fetuin$\mathrm{A}<400 \mu \mathrm{g} / \mathrm{ml}$ is $32 / 60$ patients, $11 / 30$ control subjects, fetuin- $\mathrm{A}<500 \mu \mathrm{g} / \mathrm{ml}$ is $35 / 60$ patients, $13 / 30$ control subjects, and fetuin- $\mathrm{A}<600 \mu \mathrm{g} / \mathrm{ml}$ is $42 / 60$ patients, $13 / 30$ control subjects.

\section{DISCUSSION}

\section{Comparison between FS patients and control groups}

Median serum fetuin-A was significantly low $(\mathrm{p}=0.008)$ in FS patients $(375.4 \mu \mathrm{g} / \mathrm{ml})$ as compared with the controls $(652.3 \mu \mathrm{g} / \mathrm{ml})$, as presented in Table 1 , confirming the nature of fetuin- $\mathrm{A}$ as a negative acute phase reactant that decreases in the infection and inflammation states (19-21).The infection, either bacterial or viral, is the common cause of FS (22), therefore, the decrease in fetuin- $\mathrm{A}$ is due to the infection. The decrease of serum fetuin-A in infection and inflammation is due to the counter-regulation by some proinflammatory cytokines. This phenomenon lead to classifying it as a negative acute phase reactant protein $(2,23)$.

Procalcitonin is another parameter of infection that showed a significant increase $(\mathrm{p}<0.001)$ in FS patients compared with that of the control group (Table 1), that has been discussed previously (24).PCT increases in bacterial infection and is an accurate predictor of a serious bacterial infection $(12,25)$.

Forty-three out of sixty patients $(71.7 \%)$ had serum procalcitonin higher than $0.5 \mathrm{ng} / \mathrm{ml}$. Eighteen out of 43 patients $(41.9 \%)$ with high procalcitonin had bacterial infection and responded to antibiotic treatments; the patients were discharged from hospital within several days. A previous study showed that a high percentage of patients with bacterial infection have high serum procalcitonin (26).

In the present study, there is no difference in fetuin-A and procalcitonin levels between sexes and no effect of the age on the level of fetuin-A or procalcitonin. Serum fetuin-A concentrations are independent of age and gender in a healthy pediatric population and are well comparable with those determined in adults with the same assay (27).

\section{Kernel density distributions}

Kernel density estimation is a non-parametric way to estimate the probability density function of a random variable. The model of value at risk can be predicted through the kernel density estimation of a random variable (28). Figure 1 and 2 showed the estimation of the distribution of individual fetuin-A and procalcitonin level in the patient and control groups, respectively. The results in Figure 1 show that the distribution of individual values is converging in the FS patients and healthy controls despite a moral difference. This feature is an important property of kernel density estimates shape compared to other forms of statistics. In Figure 2, most of the values of the controls are concentrated in a narrow area on the $\mathrm{x}$-axis and showed a sharp peak on the y-axis, whereas the values of procalcitonin of the patients are distributed on a wider range and may spread to take a various values. This fact indicates that procalcitonin produces a better individual difference than fetuin-A in patients as compared with the control group.

\section{Comparison between positive and negative CRP patient groups}

The decrease in the serum fetuin-Aand the increase in procalcitonin in FS patients with positive 
CRP in comparison with FS patients with negative CRP (Table 2) confirms the infection as the main cause of FS in these children.

The increase in CRP levels indicates the presence of infection (29); hence, the infection induces the increase in the PCT, as reported in other studies (30). Another study reported that fetuin-A levels are significantly correlated with CRP (31).The infected neonates who had usually positive CRP had significantly lower serum fetuin-A concentration than the controls confirming that it also behaves as a negative acute phase reactant in neonates (16).

It is found that serum fetuin-A level was decreased in endotoxemia and sepsis, supporting the concept that fetuin-A acts as a negative acute phase reactant protein in FS children. Many studies reviewed by Becker et al. (32) showed that the inhibitory effect of fetuin-A on the late mediators of endotoxemia and sepsis confers partly the protection against the bacterial invasion (2).

Measuring the procalcitonin can be regarded as an indicator of inflammation and sepsis. The elevation in the serum procalcitonin can occur in diseases other than inflammation so it cannot be considered alone as an indicator of inflammation, or sepsis. However, procalcitonin seems to be a promising marker of infections $(33,34)$ because, in many cases, it performs better than leukocyte count and CRP for detecting serious bacterial infection among febrile children and can be used efficiently for ruling out serious bacterial infection than for ruling it in $(35,36)$.

\section{Comparison between FS patients with positive and negative blood culture}

The percentage of the FS patients with positive blood culture was $13.3 \%$ in comparison with a previous study $(37,38)$. It seems that Iraqi FS patients included are at higher risk of having bacterial infections. In the Teach and Geil study (37), only 3\% of patients with bacterial infection had FS in comparison with $28.3 \%$ of FS patients who had positive blood culture (39). In the present study, patients had an FS symptom and not a disease that may be due to different etiologies. Some of our patients had bacterial infection, as shown by positive blood culture and their good response to antibiotics. The most common cause of this bacterial infection may be due to the environmental pollution and hospital-acquired infection in the Holly Karbala City. The probability of the bacterial infection increases in
Iraq due to the wars and their consequences on the health and other related services that the government cannot supply efficiently to the people. The good response of the FS patients to antibiotics confirms our results.

All of the FS patients with positive blood culture had the following criteria - CRP $>6 \mathrm{mg} / \mathrm{l}$, procalcitonin $>0.5 \mathrm{ng} / \mathrm{ml}$, fetuin-A $<600 \mu \mathrm{g} / \mathrm{ml}$. These findings can be used to substitute the culture by these tests for the diagnosis of septicemia. These rapid tests are done within hours in comparison with blood culture that takes days.

During endotoxemia or sepsis, multiple early cytokines (such as TNF-a and IFN-c) are responsible for counter-regulating hepatic fetuin-A expression. Therefore, the increase in serum TNF-a and IFN-c reduced the circulating fetuin-A levels by inhibiting fetuin-A expression $(2,40)$. These cytokines' levels should be considered in the explanation of the reduction of fetuin-A in FS patients.

A positive procalcitonin is a sensible tool with moderate specificity at 48 hour after the clinical diagnosis of neonatal sepsis (41). Elevation of procalcitonin level is used as a rapid marker to identify bacteremia (42). Furthermore, procalcitonin increased and was correlated with CRP in patients with FS during the first hour of attack (39). The comparison between the patients with negative and positive blood culture results showed that there are significant differences $(\mathrm{p}<0.05)$ between positive and negative blood culture groups in the level of procalcitonin. Higher PCT level in patients with positive blood culture was noticed in recent work (43).

\section{Correlation between fetuin-A and procalcitonin}

The results of Table 3 showed a highly significant inverse correlation between these parameters in the patient group and a lack of correlation in the control group. The procalcitonin increased as the fetuin-A decreased. In one research that studied the correlation between fetuin-A and procalcitonin, there were significant correlations between fetuin-A and procalcitonin in subjects with acromegaly (44).It seems that these two parameters are linked to infection and inflammation in a manner that differ from their correlation with other pathological diseases like acromegaly. Fetuin-A acts as a negative acute phase reactant protein and procalcitonin acts as an acute phase reactant proteins 
in FS patients, especially who are diagnosed with infection. These two parameters do not have any correlation in healthy control children who had no infection(16).

\section{Sensitivity, specificity and accuracy}

To compare the diagnostic values of either fetuin-A and procalcitonin for the diagnosis of infection, procalcitonin showed a better sensitivity and specificity than fetuin-A. Procalcitonin is useful as an alternative of the blood culture in the previous study that involved a larger sample size (45). Fetuin-A act as a moderately useful diagnostic parameter when the cut-off value is lower than $600 \mu \mathrm{g} / \mathrm{ml}$. In animal models of sepsis, the reduction in the fetuin-A levels was paralleled by the contrast elevation of serum high-mobility group box 1 protein levels (46). Furthermore, inflammation itself reduces fetuin-A in the human body (47). The correlation of fetuin-A with inflammation is due to the fact that fetuin-A can bind other anti-inflammatory molecules such as spermine (48).The serum fetuin-A concentration in the control neonates was significantly higher than that of healthy older children and reported values in adult controls. The relatively higher levels of the fetuin-A observed in this study in neonates may be related to the active bone mineralization taking place in the newborn period (16). Fetuin-A, a prototypic systemic inhibitor protein of mineralization, mediates the formation of stable colloidal mineral-protein complexes called calciprotein particles. Fetuin-A also acts as a carrier for lipids, which may influence calcification, inflammation, and apoptosis (49).

\section{CONCLUSION}

Fetuin-A and procalcitonin can be used efficiently to diagnose bacterial infection in FS children. However, procalcitonin has better sensitivity and specificity than fetuin-A.

\section{References}

1. Patterson JL, Carapetian SA, Hageman JR, Kelley KR. Febrile Seizures. Pediatric Annals. 2013; 42(12): e258-63.

http://dx.doi.org/10.3928/00904481-20131122-09

2. Phillips RS, Wade R, Lehrnbecher $\mathrm{T}$, et al. Systematic review and meta-analysis of the value of initial biomarkers in predicting adverse outcome in febrile neutropenic episodes in children and young people with cancer. BMC Medicine 2012; 10:1-13.

http://dx.doi.org/10.1186/1741-7015-10-6

3. Li W, Zhu S, Li J, Huang Y, Zhou R, et al. A Hepatic Protein, Fetuin-A, Occupies a Protective Role in Lethal Systemic Inflammation. PLoS ONE. 2011: 6(2): e16945.

http://dx.doi.org/10.1371/journal.pone.0016945

4. Lan JH, Wu RH, Lv ZC. (Serum CD4+ and CD8+ levels and the CD4+/CD8+ ratio in children with febrile convulsion). Zhongguo Dang Dai ErKeZaZhi 2009:11(6):492-3.
5. Moreira VG, Prieto B, Rodríguez JS, Alvarez FV. Usefulness of cell-free plasma DNA, procalcitonin and C-reactive protein as markers of infection in febrile patients. Ann ClinBiochem. 2010:47(Pt3):253-8.

http://dx.doi.org/10.1258/acb.2010.009173

6. Mikkonen K, Pekkala N, Pokka T, Romner B, Uhari M, Rantala H. S100B proteins in febrile seizures. Seizure. 2012: 21(2):144-6.

http://dx.doi.org/10.1016/j.seizure.2011.10.006

7. Haberlandt E, Rauchenzauner M, Morass M, et al. Matrix-metalloproteinases and proinflammatory cytokines in children with febrile convulsions and epilepsy--cause or consequence? Epilepsy Res 2013:105(1-2):225-8.

http://dx.doi.org/10.1016/j.eplepsyres.2012.12.003

8. Hessel EV, de Wit M, Wolterink-Donselaar IG, et al. Identification of Srp9 as a febrile seizure susceptibility gene. Ann ClinTranslNeurol 2014:1(4):239-50.

http://dx.doi.org/10.1002/acn3.48 
9. Stöcklin B, Fouzas S, Schillinger P, et al.Copeptin as a serum biomarker of febrile seizures.PLoS One 2015:10(4):e0124663. http://dx.doi.org/10.1371/journal.pone.0124663

10. Qu J, L X, Liu Y, Wang X. Evaluation of procalcitonin, C-reactive protein, interleukin-6 \&amp; serum amyloid $A$ as diagnostic biomarkers of bacterial infection in febrile patients. Indian J Med Res 2015:141(3):315-21. http://dx.doi.org/10.4103/0971-5916.156617

11. Xu RY, Liu HW, Liu JL, DongJHua. Procalcitonin and C-reactive protein in urinary tract infection diagnosis. BMC Urol 2014; 14: 1-5. http://dx.doi.org/10.1186/1471-2490-14-45

12. Kitanovski L, Jazbec J, Hojker S, Derganc M. Diagnostic accuracy of lipopolysaccharidebinding protein for predicting bacteremia/clinical sepsis in children with febrile neutropenia: comparison with interleukin-6, procalcitonin, and C-reactive protein.Support Care Cancer 2014: 22:269-77.

http://dx.doi.org/10.1007/s00520-013-1978-1

13. Luaces-Cubells C, Mintegi S, García-García JJ, et al. Procalcitonin to detect invasive bacterial infection in non-toxic-appearing infants with fever without apparent source in the emergency department.Pediatr Infect Dis J 2012: 31:645-7. http://dx.doi.org/10.1097/INF.0b013e31824dacf4

14. Heiss A, Eckert T, Aretz A, et al. Hierarchical role of fetuin-A and acidic serum proteins in the formation and stabilization of calcium phosphate particles. J BiolChem 2008: 23;283(21):14815-25. http://dx.doi.org/10.1074/jbc.M709938200

15. Smith ER, Cai MM, McMahon LP, Pedagogos E, Toussaint ND, Brumby C, Holt SG. Serum fetuin-A concentration and fetuin-A-containing calciprotein particles in patients with chronic inflammatory disease and renal failure. Nephrology (Carlton) 2013: 18(3):215-21. http://dx.doi.org/10.1111/nep.12021

16. Abiodun PO, Olomu IN. Alpha 2 HSglycoprotein levels in children with proteinenergy malnutrition and infections. J PediatrGastroenterolNutr 1987: 6(2):271-5. http://dx.doi.org/10.1097/00005176-19870300000019
17. Dubreuil JD, Giudice GD, Rappuoli R. Helicobacter pylori interactions with host serum and extracellular matrix proteins: potential role in the infectious process. MicrobiolMolBiol Rev 2002: 66(4):617-29.

http://dx.doi.org/10.1128/mmbr.66.4.617-629.2002

18. Bell CW, Jiang W, Reich CF, Pisetsky DS. The Extracellular Release of HMGB1 during Apoptotic Cell Death. Am J Physiol Cell Physiol 2006: 291(6): C1318-25.

http://dx.doi.org/10.1152/ajpcell.00616.2005

19. Wang H, Sama AE Anti-inflammatory role of Fetuin-A in Injury and Infection. CurrMol Med 2012: 12(5): 625-33.

http://dx.doi.org/10.2174/156652412800620039

20. Oncu K, Yazgan Y, Tanoglu A, et al. Can serum fetuin-A be regarded as an inflammatory marker among patients with familial Mediterranean fever? Dig Dis Sci 2013: 58(11):3212-7. http://dx.doi.org/10.1007/s10620-013-2814-7

21. Muratli S, Uzunlulu M, Gonenli G, Oguz A, Isbilen B. Fetuin $A$ as a new marker of inflammation in Hashimoto thyroiditis. Minerva Endocrinol 2015: 40(1):9-14.

22. Innes RF. Understanding the pathophysiology behind febrile convulsions. Nurs Child Young People 2015: 27(2):20-3.

http://dx.doi.org/10.7748/ncyp.27.2.20.e497

23. Ohnishi T, Nakamura O, Ozawa $\mathrm{M}$, et al. Molecular cloning and sequence analysis of cDNA for a $59 \mathrm{kD}$ bone sialoprotein of the rat: demonstration that it is a counterpart of human alpha 2-HS glycoprotein and bovine fetuin. J Bone Miner Res 1993: 8: 367-77. http://dx.doi.org/10.1002/jbmr.5650080314

24. Xiao-Yan SU, Shun-Hang WEN, Li LIN, ChangChong LI. Clinical characteristics of children with Streptococcus pneumoniae septicemia and drug sensitivity of Streptococcus pneumonia. Chin J ContempPediatr 2013:11: 995-9.

25. Haeusler GM, Carlesse F, Phillips RS. An updated systematic review and meta-analysis of the predictive value of serum biomarkers in the assessment of fever during neutropenia in 
children with cancer.Pediatr Infect Dis J 2013;32:e390-6.

http://dx.doi.org/10.1097/INF.0b013e31829ae38d

26. Markic J, Jeroncic A, Polancec D, et al. CD15s is a potential biomarker of serious bacterial infection in infants admitted to hospital.Eur J Pediatr 2013;172:1363-9.

http://dx.doi.org/10.1007/s00431-013-2047-y

27. Wigger M, Schaible J, Muscheites J, Kundt G, Haffner D, Fischer DC. Fetuin-A serum concentrations in healthy children. Ann ClinBiochem 2009: 46(Pt 6):511-3.

http://dx.doi.org/10.1258/acb.2009.009037

28. Chen R, Wang Z. Curve Fitting of the Corporate Recovery Rates: The Comparison of Beta Distribution Estimation and Kernel Density Estimation. PLoS ONE 2013: 8(7): e68238. http://dx.doi.org/10.1371/journal.pone.0068238

29. Wu X, Wang CQ, Yan XF, et al. Clinical features and molecular characteristics of methicillinresistant Staphylococcus aureus in children. ZhonghuaErKeZaZhi 2013;51:512-517.

30. Galetto-Lacour A, Gervaix A. Identifying severe bacterial infection in children with fever without source.Expert Rev Anti Infect Ther2010: 8:1231-7. http://dx.doi.org/10.1586/eri.10.118.

31. Ou HY, Yang YC, Wu HT, Wu JS, Lu FH, Chang CJ. Serum fetuin-A concentrations are elevated in subjects with impaired glucose tolerance and newly diagnosed type 2 diabetes.ClinEndocrinol (Oxf) 2011: 75(4):450-5. http://dx.doi.org/10.1111/j.1365-2265.2011.04070.x

32. Becker KL, Snider R, Nylen ES. Procalcitonin assay in systemic inflammation, infection, and sepsis: clinical utility and limitations. Crit Care Med 2008, 36:941-52.

http://dx.doi.org/10.1097/CCM.0B013E318165BA BB

33. Dimitri E, Amialyanchyk V, D'Angelo G, et al. Diagnostic approach to flogosis: procalcitoninvalidity. Minerva Pediatr 2013;65:167-72.

34. Tsalkidou EA, Roilides E, Gardikis S, et al. Lipopolysaccharide-binding protein: a potential marker of febrile urinary tract infection in childhood.PediatrNephrol 2013:28(7):1091-7. http://dx.doi.org/10.1007/s00467-013-2432-9

35. Kasem AJ, Bulloch B, Henry $\mathrm{M}$, et al. Procalcitonin as a marker of bacteremia in children with fever and a central venous catheter presenting to the emergency department.PediatrEmerg Care 2012:28:1017-21. http://dx.doi.org/10.1097/PEC.0b013e31826caac2

36. Yo CH, Hsieh PS, Lee SH, et al. Comparison of the test characteristics of procalcitonin to Creactive protein and leukocytosis for the detection of serious bacterial infections in children presenting with fever without source: a systematic review and meta-analysis.AnnEmerg Med 2012:60:591-600.

http://dx.doi.org/10.1016/j.annemergmed.2012.05 .027

37. Teach SJ, Geil PA. Incidence of bacteremia, urinary tract infections, and unsuspected bacterial meningitis in children with febrile seizures. PediatrEmerg Care 1999;15(1):9-12. http://dx.doi.org/10.1097/00006565-19990200000003

38. Shah SS1, Alpern ER, Zwerling L, Reid JR, McGowan KL, Bell LM. Low risk of bacteremia in children with febrile seizures. Arch PediatrAdolesc Med 2002: 156(5):469-72. http://dx.doi.org/10.1001/archpedi.156.5.469

39. Al-Hakeim HK, Al-Hillawi ZM, Al-Kindi MA. Procalcitonin, Calcium, and Magnesium in Patients with Febrile Seizure during One-Hour Attack. Br J Med Med Res 2015:6(6): 617-24. http://dx.doi.org/10.9734/BJMMR/2015/13252

40. Daveau M, Christian D, Julen N, Hiron M, Arnaud $\mathrm{P}$, et al. The synthesis of human alpha-2HS glycoprotein is down-regulated by cytokines in hepatoma HepG2 cells. FEBS Lett 1988: 241: 191-4.

http://dx.doi.org/10.1016/0014-5793(88)81059-7

41. Reitman AJ, Pisk RM, Gates JV 3rd, Ozeran JD. Serial procalcitonin levels to detect bacteremia in febrile neutropenia.ClinPediatr (Phila) 2012:51:1175-83.

http://dx.doi.org/10.1177/0009922812460913

42. Hattori $\mathrm{T}$, Nishiyama $\mathrm{H}, \mathrm{Kato} \mathrm{H}$, et al. Clinical value of procalcitonin for patients with 
suspected bloodstream infection. Am J ClinPathol 2014:141(1):43-51.

http://dx.doi.org/10.1309/ajcp4gv7zfdtangc

43. Ramírez-Valdivia JM, Pérez-Molina JJ, LocheoGonzález M, et al. Procalcitonin a marker in the diagnostic of the newborn with systemic infection. Rev Med InstMexSeguroSoc 2008:46:597-602.

44. Topsakal S, Akin F, Turgut S, Yaylali G, Herek D, Ayada C. Relationship of apelin, procalcitonin, and fetuin-A concentrations with carotid intimamedia thickness in acromegaly. Ann ClinBiochem 2014:.pii: 0004563214562431.

45. Arai T, Kumasaka K, Nagata K, et al.Prediction of blood culture results by measuringprocalcitonin levels and other inflammatory biomarkers. Am J Emerg Med 2014;32(4):330-3.

http://dx.doi.org/10.1016/j.ajem.2013.12.035
46. Yang $\mathrm{H}$, Ochani $\mathrm{M}, \mathrm{Li} \mathrm{J}$, et al. Reversing established sepsis with antagonists of endogenous high-mobility group box 1 . Proc Nat AcadSciUSA 2004; 101(1):296-301. http://dx.doi.org/10.1073/pnas.2434651100

47. Moe SM1, Chen NX. Inflammation and vascular calcification. Blood Purif 2005;23(1):64-71. http://dx.doi.org/10.1159/000082013

48. Wang H, Zhang M, Soda K, Sama A, Tracey KJ. Fetuin protects the fetus from TNF (letter). Lancet 1997: 350: 861-2. http://dx.doi.org/10.1016/S0140-6736(05)62030-2

49. Brylka L1, Jahnen-Dechent W. The role of fetuin$A$ in physiological and pathological mineralization. Calcif Tissue Int 2013;93(4):35564.

http://dx.doi.org/10.1007/s00223-012-9690-6 


\title{
Efikasnost fetuina-A i prokalcitonina u dijagnostikovanju infekcije kod bolesne dece sa febrilnim konvulzijama
}

\author{
Hussein Kadhem Al-Hakeim¹, Azhar Mohammed Al-Ankoshy², Mohammed-R.Alsharifi² \\ ${ }^{1}$ Univerzitet u Kufi, Fakultet nauka, Departman za hemiju, Irak \\ ${ }^{2}$ Univerzitet za prirodne i društvene nauke, Departman za tehnike patoloških analiza, Najaf, Irak
}

\section{SAŽETAK}

Fetuin-A je negativni reaktant akutne faze, a prokalcitonin (PCT) je indikator ozbiljne bakterijske infekcije. Dijagnoza bakterijske infekcije kod febrilnih konvulzija (FK) je važna zbog izbora najadekvatnije terapije. U ovoj studiji je po prvi put procenjen fetuin-A kod bolesnika sa FK, a zatim upoređen sa vrednostima prokalcitonina i rezultatima krvne slike.

U studiji je učestvovalo ukupno 60 dece (28 dečaka i 32 devojčice) sa febrilnim konvulzijama, kao i tridesetoro dece koja su po polu i uzrastu odgovarala deci iz ispitivane grupe. Bolesnici su podeljeni prema polu, uzrastu, nivou PCT-a (visok PCT $>0,5 \mathrm{ng} / \mathrm{mL}$ ), nivoima C-reaktivnog proteina (CRP) (pozitivan CRP $>6$ $\mathrm{mg} / \mathrm{L}$ ) i prema rezultatima krvne slike.

Nivo fetuina-A se smanjio, dok je nivo PCT-a porastao kod dece sa FK u poređenju sa kontrolnom grupom. Ove vrednosti su značajno povećane $(p<0,05)$ u grupi sa pozitivnim CRP-om u poređenju sa grupom sa negativnim CRP-om. Procena raspodele skupa podataka je pokazala da je prokalcitonin bolji pokazatelj infekcije kod dece sa febrilnim konvulzijama u odnosu na fetuin-A. Prokalcitonin je senzitivniji i osetljiviji nego fetuin-A, a kada se koriste zajedno za dijagnostikovanje bakterijske infekcije kod dece sa febrilnim konvulzijama, procenat senzitivnosti i specifičnosti je $100 \%$.

Nivo fetuina-A je nizak kod dece sa febrilnim konvulzijama i u kombinaciji sa prokalcitoninom se koristi u dijagnostikovanju infekcije kod febrilnih konvulzija.

Ključne reči: fetuin-A, prokalcitonin, infekcija, febrilna konvulzija 